\title{
LISTS OF SPANISH SENTENCES WITH EQUIVALENT PREDICTABILITY, PHONETIC CONTENT, LENGTH, AND FREQUENCY OF THE LAST WORD ${ }^{1}$
}

TERESA CERVERA

University of Valencia
JULIO GONZÁLEZ-ALVAREZ

University Jaume I

Summary. - This paper presents a pool of Spanish sentences designed for use in cognitive research and speech processing in circumstances in which the effects of context are relevant. These lists of sentences are divided into six lists of 25 equivalent high-predictability sentences and six lists of 25 low-predictability sentences according to the extent to which the last word can be predicted by the preceding context. These lists were also equivalent in phonetic content, length and frequency of the last word. These lists are intended for use in psycholinguistic research with Spanish-speaking listeners.

The assessment of the effects of context on recognition of spoken words has been the subject of extensive research in cognitive science and language processing. It has been firmly established that a preceding context favors the recognition of a word compared to words in isolation (Miller, Heise, \& Lichten, 1951; Duffi \& Giolas, 1974). The context imposes syntactic and semantic constraints which increase the predictability of the last word in the sentence.

The evaluation of speech intelligibility is a specific area of research in which this question is especially relevant. If the intention of the researcher is to approach everyday communicative situations as much as possible, then sentences are the most appropriate speech stimuli. However, in the recognition of sentences, sensory or bottom-up information interacts with top-down or linguistic information provided by the sentence's context. The most frequent way to assess the relative contribution of bottom-up and top-down information has been to present to listeners short sentences containing a contextual part and a final word. The listeners must respond by providing the final word. The contribution of the context to the recognition of the final word can be assessed by comparing the proportion of correct responses in high-predictability sentences with the responses in low-predictability sentences, on the assumption that increased contextual information contributes to a better understanding of the final word (Kalikow, Stevens, \& Elliot, 1977).

The evaluation of speech intelligibility is especially important in certain situations such as background noise or with certain types of lis-

\footnotetext{
${ }^{1}$ Address correspondence to Teresa Cervera, Ph.D., Departamento de Psicología Básica, Uni-
} versitat de Valencia, Blasco Ibanez 21, 46010 Valencia, Spain or email (Teresa.Cervera@uv.es). 
teners such as elderly persons (Perry \& Wingfield, 1994; Pichora-Fuller, Schneider, \& Daneman, 1995; Gordon-Salant \& Fitzgibbons, 1997; Sommers \& Danielson, 1999; Dubno, Ahlstrom, \& Horwitz, 2000; Wingfield, Tun, \& McCoy, 2005; Pichora-Fuller, 2008). In such listeners, decreases in sensory information due to loss of auditory acuity, especially under adverse listening conditions involving background noise or voices, can be compensated by top-down information provided by the context. With the aim of equating perceptual properties of the sentences, speech materials are constructed to be equivalent in certain relevant characteristics such as length and phonetic content. In addition, the properties of the final word or target word must be controlled. Thus, these words must also be equivalent in their main characteristics such as length, syntactic category (nouns are usually used), stress, and, principally, frequency of the word. The influence of word frequency on spoken-word recognition is well-known since the studies of Samuel (1981) and Marslen-Wilson (1987), and plays a fundamental role in speech perception theories (Forster, 1981; McClelland \& Elman, 1986; Marslen-Wilson, 1987).

In the English language, the speech materials which satisfy all of these requisites are the SPIN (Speech Perception in Noise) sentences (Kalikow, et al., 1977). In these materials, two types of sentences are used: high-predictability sentences whose final word can be somewhat predicted by the preceding context, and low-predictability sentences whose final word cannot be predicted by the context. The same final words appear in the high- and low-predictability sentences. By comparing the recognition performance of individuals on these two types of sentences, separate effects of auditory acuity and cognitive processing, expressed as capability of using the context to recognize the final word, can be assessed. This type of testing is especially important for elderly listeners because they frequently present with age-related decreased auditory acuity (presbycusis) and, in some cases, age-related cognitive decline (Committee for Hearing, Bioacoustics, and Biomechanics, 1988). Better performance on high- than on low-predictability sentences is expected to be independent of the hearing status of the listeners. Thus, if no such differences are found, some deficiencies in cognitive processing might be suspected.

The effect of context on recognition of the subsequent word for other types of listeners also is a relevant issue. One example would be nonnative listeners having differences in second language proficiency. Nonnative speech communication is known to be less effective than native communication (Flege, 1995). Nonnative listeners take less advantage of the context than native listeners do. Differences in the recognition of highand low-predictability sentences would presumably indicate the extent to which the nonnative listeners are fluent enough to profit from the se- 
mantic and syntactic information provided by context (Mayo, Florentine, \& Buus, 1997). Thus, the use of high- and low-predictability sentences is appropriate for assessing the type of sensory or cognitive processes involved in sentence processing by bilingual listeners. In addition, the use of high- and low-predictability sentences by audiologists has demonstrated their efficacy in the evaluation of hearing-impaired listeners (Hutcherson, Dirks, \& Morgan, 1979).

Several listening conditions have been used in examining high- and low-predictability sentences, including background noise at different signal-to-noise levels (Kalikow, et al., 1977; Gordon-Salant \& Fitzgibbons, 1999, 2001, 2004; Dubno, et al., 2000; Gordon-Salant, Fitzgibbons, \& Friedman, 2007; Humes, Burk, Coughlin, Busey, \& Strauser, 2007), fast speech (Gordon-Salant \& Fitzgibbons, 1999, 2001, 2004; Humes, et al., 2007; Gordon-Salant, et al., 2007), same versus different speakers' voices (Goy, Pichora-Fuller, van Lieshout, Singh, \& Schneider, 2007), or some speech distortions such as jitter (Pichora-Fuller, Schneider, MacDonald, Pass, \& Brown, 2007) or noise-vocoded speech (Sheldon, Pichora-Fuller, \& Schneider, 2008).

The high- and low-predictability sentences have also been used to evaluate the extent to which elderly listeners may benefit from context, both in perception and recall. Working memory capacity (Baddeley \& Hitch, 1974) was assessed by Pichora-Fuller, et al. (1995) using an auditory version of the Daneman and Carpenter task for reading materials (Daneman \& Carpenter, 1983). In the study by Pichora-Fuller, et al. (1995), participants were asked to report the final word of the sentence immediately after hearing the sentence and to successively maintain a number of these final words in memory until they were asked to recall them at the end of a set of sentences. Finally, the availability of several equivalent lists of highand low-predictability sentences is useful when it is necessary to test the same individuals on several occasions over a period of time.

Although these questions are interesting regardless of the native language of the individuals, most studies have been conducted with Englishspeaking participants and English-language materials. To date, there are no sets of high- and low-predictability sentences in the Spanish language similar to those for the English language (SPIN sentences) for use by researchers and clinicians. The Hearing in Noise Test (HINT), originally developed by Nilsson, Soli, and Sullivan (1994) and adapted to the Castilian Spanish language by Huarte (2008), uses sentences as speech material but the distinction between high and low predictability is not contemplated in these lists. In the present study, equivalent sets of high- and low-predictability sentences were generated. The final pool consisted of six high-predictability lists of sentences, and six low-predictability lists, each list com- 
prising 25 sentences. These lists were equivalent on predictability, but also on other characteristics such as length, phonetic content (both the whole sentence and the last word), syllabic structure, word stress, and frequency of the final word. The length of the sentence is an important characteristic because processing the sentence cannot take so long that it requires extensive memory. It is also important because there is a positive relation between sentence length and effects of the context on the recognition of the last word (van Petten \& Kutas, 1990). On the other hand, as the sentences are constructed for use in differentially assessing sensory and cognitive processing of the sentence, an important property of the sentence (including the last word) which must be balanced is the phonetic content.

At the same time, controlling the characteristics of the last word is also important, as this word (rather than the whole sentence) is normally required as a response because it simplifies the listener's task, and it is faster and easier for the researcher or clinician to evaluate. The last words used in the present study were also equivalent in frequency of occurrence. All the words are bisyllabic and accented on the first syllable (instead of the monosyllabic words used in the English language) because this structure is the most frequent one in the Spanish language. These lists of sentences, which are equivalent in predictability, length, and final word frequency, are suitable for use in psycholinguistic research with Spanish-speaking participants in those circumstances in which sensory reception and cognitive processing (context effects) are important factors to be considered.

\section{Method}

\section{Procedure}

Selecting the last word of sentences. - The first step in generating the sentences was to select the words which would be the last words in the sentences. After that, the sentences were generated. Following the procedure by Kalikow, et al. (1977), the last word in the sentence must be a noun, but it has to be bisyllabic and have the stress on the first syllable as this is the most representative syllabic structure in Spanish, rather than the monosyllabic words preferably used in the English language. Another requirement was that all the words have a similar frequency index. The words could not be little used or very frequently used. The measure of frequency of occurrence used was one word per million in the Spanish written language from the Alameda and Cuetos' corpus (1995). The words selected had a frequency of between 16 and 41 per million, and they were nouns, bisyllabic, and stressed on the first syllable. The initial pool consisted of 240 words.

Generation of sentences. - The next step was to generate a high-predictability sentence and a low-predictability sentence for each of the 240 
words. The low-predictability sentences were formed with the target word preceded by a neutral context such as "No temas hablar de ..." ("Don't be afraid to talk about..." ) or "Carlos habló sobre ..." ("Carlos talked about ..."). The high-predictability sentences were generated by using the last word preceded by a context semantically connected with that word, such as "Llegó una hora tarde a su cita" (He/she arrived an hour later to his/her appointment") or "Tengo el dinero en el banco" ("I have the money in the bank"), but without the key word being the only possible word. Proverbs, sayings, maxims, adages, etc., were avoided. All sentences with both high and low predictability had a similar length of seven to 10 syllables, and they had a variety of syntactic structures.

Predictability of the sentences and initial selection. - The 210 high-predictability sentences were judged on their predictability by a group of 150 participants, students at the University of Valencia from 21 to 26 years of age who participated voluntarily and gave their informed consent. All the sentences were presented as a paper-and-pencil test without the last word in the sentence (e.g., "Tengo el dinero en el ...," "I have the money in the..."). The listeners were instructed to fill in the last word of the sentence according to what they thought was the most likely word to occur. They were told that the last word was a bisyllabic noun stressed on the first syllable. The task was performed in different sessions over a period of several weeks.

For each sentence, the number of responses which coincided with the last word, transformed into percentages (of the total number of participants' answers), was taken as the measure of sentence predictability. From the initial pool of 240 sentences, those sentences whose predictability was between $10 \%$ and $90 \%$ were selected. This way, the sentences of very high or very low predictability were excluded. The total number of selected sentences was 168 . Of these 168 sentences, 150 were randomly selected and randomly assigned to the six lists of 25 high-predictability sentences. The 18 remaining sentences were not used.

The means and the standard deviations for the values of predictability for each of the six lists of sentences were calculated (Table 1). As the intention was to have lists homogeneous in predictability values, the present objective was to obtain similar mean values for all the lists. To confirm that the six lists did not differ statistically on their predictability values, a one-way ANOVA was conducted with the predictability scores for each sentence (expressed in percent) as a dependent variable and the list to which the sentences belonged (list) as an independent variable with six levels. Analysis showed no significant effects of list $(F=0.59, p>.05$; $\eta^{2}=0.02$ ), therefore, the six lists did not differ with respect to the predictability of the last word. 
TABLE 1

Means and Standard Deviations For the Measures of Predictability (\%) and Frequency of the Last Word in the Sentence in the List of High-predictability Sentences

\begin{tabular}{lllllr}
\hline \hline & \multicolumn{2}{c}{ Predictability } & & \multicolumn{2}{c}{ Frequency } \\
\cline { 2 - 3 } \cline { 5 - 6 } & $M$ & $S D$ & & $M$ & $S D$ \\
\hline List 1 & 0.40 & 0.23 & & 26.50 & 12.48 \\
List 2 & 0.39 & 0.24 & & 26.72 & 7.34 \\
List 3 & 0.38 & 0.26 & & 28.50 & 8.33 \\
List 4 & 0.36 & 0.23 & & 31.36 & 15.01 \\
List 5 & 0.38 & 0.22 & & 28.90 & 14.38 \\
List 6 & 0.40 & 0.28 & & 25.86 & 14.38 \\
\hline
\end{tabular}

Frequency of the last word. - From the initial pool of 240 words selected from Alameda and Cuetos' corpus (1995), only 150 (six lists of 25 sentences, Table 1) were finally used in a preceding high- or low-predictability sentence, as explained above. Because it was necessary to test whether the frequency values of the last word were similar for the six lists, a one-way ANOVA was conducted on values of frequency of the last word, obtained from Alameda and Cuetos' corpus (1995) as the dependent variable, and list as the independent variable with six levels. There were no significant effects of list $\left(F=0.11, p>.05 ; \eta^{2}=0.05\right)$, indicating that the six lists did not differ with respect to the frequency of the last word.

Phonetic content. - Another aim of the present study was for the six lists of 25 high-predictability sentences to have similar phonetic content in case these lists were to be used in intelligibility experiments. For this purpose, the phonetic balance of the speech materials should be controlled. For the low-predictability sentences this question was not as relevant because the same 25 preceding contexts were used in each of the six lists. The phonetic counts were performed separately for the last words of the 150 high-predictability sentences and for the whole high-predictability sentence (the preceding context plus the last word). In these counts, only content words (verbs, nouns, and adjectives) were taken into account, and articles, prepositions, and adverbs were not considered. The phonetic count was calculated by counting the number of occurrences of segments in each phoneme class (occlusives, fricatives, nasals, liquids, and vowels). Phonetic content calculations were performed by the authors. No special training in phonetics is needed for this task because the correspondence between phoneme and letter is almost biunivocal in the Spanish language.

A distribution of frequencies for each phoneme class was obtained for each of the 150 sentences (the whole sentence). The total distribution made it possible to specify whether any of the sentences deviated in the number of occurrences in any of the phoneme classes. For instance, the table of frequencies for the occlusives showed that most of their values ranged from 
1 to 4 , and only one sentence had 5 occlusives. Thus, this sentence was replaced by one of the remaining 18 sentences from the initial distribution of sentences to the six lists. The new sentence had to have approximately the same predictability as the one which was replaced. Only one sentence had to be replaced by another. Table 2 shows the number of occurrences of each phoneme class for the six lists of high- and low-predictability sentences.

TABLE 2

Phonetic Counts by Number of Occurrences in Each Phoneme Class For Last Word and Whole Sentence, For Both HighPREDictability (HP) AND Low-PREdictability (LP) SENTENCES

\begin{tabular}{|c|c|c|c|c|c|c|}
\hline \multirow{2}{*}{ List } & \multirow{2}{*}{ Count Type } & \multicolumn{5}{|c|}{ Phoneme Class } \\
\hline & & Occlusive & Fricatives & Nasals & Liquids & Vowels \\
\hline \multirow[t]{3}{*}{ List 1} & Last word & 24 & 14 & 3 & 15 & 48 \\
\hline & HP whole sentence & 80 & 38 & 23 & 52 & 171 \\
\hline & LP whole sentence & 93 & 49 & 39 & 59 & 213 \\
\hline \multirow[t]{3}{*}{ List 2} & Last word & 21 & 10 & 7 & 15 & 48 \\
\hline & HP whole sentence & 75 & 35 & 41 & 37 & 172 \\
\hline & LP whole sentence & 90 & 45 & 43 & 59 & 210 \\
\hline \multirow[t]{3}{*}{ List 3} & Last word & 18 & 16 & 11 & 11 & 50 \\
\hline & HP whole sentence & 81 & 37 & 39 & 44 & 176 \\
\hline & LP whole sentence & 87 & 52 & 47 & 55 & 214 \\
\hline \multirow[t]{3}{*}{ List 4} & Last word & 26 & 19 & 7 & 13 & 56 \\
\hline & HP whole sentence & 71 & 49 & 25 & 48 & 184 \\
\hline & LP whole sentence & 95 & 54 & 43 & 57 & 222 \\
\hline \multirow[t]{3}{*}{ List 5} & Last word & 24 & 15 & 10 & 14 & 55 \\
\hline & HP whole sentence & 81 & 37 & 35 & 46 & 179 \\
\hline & LP whole sentence & 93 & 50 & 46 & 58 & 220 \\
\hline \multirow[t]{3}{*}{ List 6} & Last word & 26 & 15 & 10 & 15 & 50 \\
\hline & HP whole sentence & 83 & 39 & 37 & 52 & 172 \\
\hline & LP whole sentence & 95 & 50 & 46 & 59 & 219 \\
\hline
\end{tabular}

To test whether all the sentences of each type (high and low predictability) had equivalent phonetic content, a $\chi^{2}$ analysis was performed with the counts obtained from the phonetic content analysis for each sentence type. Phoneme class (occlusives, fricatives, nasals, liquids, and vowels) and list (six levels) were included as factors. The $\chi^{2}$ values were not significant for the high- or low-predictability sentences $\left(\chi^{2}=19.30, d f=20, p>.05\right.$, and $\chi^{2}=2.80, d f=20, p>.05$, respectively). Thus, the six lists of high- and low-predictability sentences did not differ in their phonetic content. The final lists of high- and low-predictability sentences are presented in the Appendix (pp.

\section{Discussion}

The objective was to generate equivalent lists of high- and low-predictability Spanish sentences, as none existed for use in the Spanish lan- 
guage. Such sentences have many applications in the psycholinguistics, especially in those circumstances in which one would be interested in assessing the sensory or bottom-up processing and the cognitive (effective use of context) or top-down processing skills of the listeners during language processing. The six lists of 25 high-predictability sentences and the equivalent six lists of 25 low-predictability sentences were generated. All sentences were equivalent on characteristics of predictability, length, and phonetic content. As the last or key word is normally used in testing effective processing of a sentence by the listener, it was also necessary to control the properties of these words: frequency of occurrence, length, stress, and phonetic content. The data showed that all the lists of high- and lowpredictability sentences were equivalent in these characteristics. These lists are intended for use in psycholinguistic research and they would be suitable for an intelligibility assessment in future studies.

\section{REFERENCES}

Alameda, J. R., \& Cuetos, F. (1995) Diccionario de frecuencias de las unidades lingüísticas del castellano. Oviedo, Spain: Servicio de Publicaciones de la Universidad de Oviedo.

Baddeley, A. D., \& Hitch, G. J. (1974) Working memory. In G. A. Bower (Ed.), Recent advances in learning and motivation. Vol. VIII. New York: Academic Press. Pp. 47-90.

Committee for Hearing, Bioacoustics, and Biomechanics. (1988) Speech understanding and aging. Journal of the Acoustical Society of America, 83, 859-895.

Daneman, M., \& Carpenter, P. A. (1983) Individual differences in integrating information between and within sentences. Journal of Experimental Psychology: Learning, Memory, and Cognition, 25, 1-18.

Dubno, J. R., Ahlstrom, J. B., \& Horwitz, A. R. (2000) Use of context by young and aged adults with normal hearing. Journal of the Acoustical Society of America, 107, 538-546.

Dufri, J. R., \& Giolas, T. G. (1974) Sentence intelligibility as a function of key word selection. Journal of Speech and Hearing Research, 17, 631-637.

FLEGE, J. (1995) Second-language speech learning: theory, findings, and problems. In W. Strange (Ed.), Speech perception and linguistic experience: issues in cross-language research. Timonium, MD: York Press. Pp. 229-273.

Forster, K. I. (1981) Frequency blocking and lexical access: one mental lexicon or two? Journal of Verbal Learning and Verbal Behavior, 20, 190-203.

Gordon-Salant, S., \& Fitzgibbons, P. J. (1997) Selected cognitive factors and speech recognition performance among young and elderly listeners. Journal of Speech and Hearing Research, 40, 423-431.

Gordon-Salant, S., \& Fitzgibbons, P. J. (1999) Profile of auditory temporal processing in older adults. Journal of Speech, Language, and Hearing Research, 42, 300-311.

Gordon-Salant, S., \& Fitzgibbons, P. J. (2001) Sources of age-related recognition difficulty for time-compressed speech. Journal of Speech, Language, and Hearing Research, 44, 709-719. 
Gordon-Salant, S., \& Fitzgibbons, P. J. (2004) Effects of stimulus and noise rate variability on speech perception by younger and older adults. Journal of the Acoustical Society of America, 115, 1808-1817.

Gordon-Salant, S., Fitzgibbons, P. J., \& Friedman, S. A. (2007) Recognition of timecompressed and natural speech with selective temporal enhancements by young and elderly listeners. Journal of Speech and Hearing Research, 50, 1181-1193.

Goy, H., Pichora-Fuller, M. K., van Lieshout, P., Singh, P., \& Schneider, B. A. (2007) Effect of within- and between-talker variability on word identification in noise by younger and older adults. Canadian Acoustics, 35, 108-109.

Huarte, A. (2008) The Castilian Spanish Hearing in Noise Test. International Journal of Audiology, 47, 369-370.

Humes, L. E., Burk, M. H., Coughlin, M. P., Busey, T. A., \& Strauser, L. E. (2007) Auditory speech recognition and visual text recognition in younger and older adults: similarities and differences between modalities and the effects of presentation rate. Journal of Speech, Language, and Hearing Research, 50, 283-303.

Hutcherson, R. V., Dirks, D. D., \& Morgan, D. E. (1979) Evaluation of the Speech Perception in Noise (SPIN) test. Otolaryngology-Head and Neck Surgery, 87, 239-245.

Kalikow, D. N., Stevens, K. N., \& Elliot, L. L. (1977) Development of a test of speech intelligibility in noise using sentence materials with controlled word predictability. Journal of the Acoustical Society of America, 5, 1337-1360.

Marslen-Wilson, W. (1987) Functional parallelism in spoken word recognition. Cognition, 25, 71-102.

Mayo, L. H., Florentine, M., \& Buus, S. (1997) Age of second-language acquisition and perception of speech in noise. Journal of Speech, Language, and Hearing Research, 40, 3, 686-693.

McClelland, J. L., \& Ellman, J. L. (1986) The TRACE model of speech perception. Cognitive Psychology, 18, 1-86.

Miller, G. A., Heise, G. A., \& Lichten, W. (1951) The intelligibility of speech as a function of the context in test materials. Journal of Experimental Psychology, 41, 329-335.

Nilsson, M., Soli, S. D., \& Sullivan, J. A. (1994) Development of the Hearing in Noise Test for the measurement of speech reception thresholds in quiet and in noise. Journal of the Acoustical Society of America, 95, 1085-1099.

Perry, A. R., \& Wingfield, A. (1994) Contextual encoding by young and elderly adults as revealed by cued and free recall. Aging and Cognition, 1, 120-139.

Pichora-Fuller, M. K. (2008) Use of supportive context by young and older adult listeners: balancing bottom-up and top-down information processing. International Journal of Audiology, 47(Suppl. 2), S72-S82.

Pichora-Fuller, M. K., Schneider, B. A., \& Daneman, M. (1995) How young and old adults listen and remember speech in noise. Journal of the Acoustical Society of America, 97, 593-608.

Pichora-Fuller, M. K., Schneider, B. A., MacDonald, E., Pass, H. E., \& Brown, S. (2007) Temporal jitter disrupts speech intelligibility. Hearing Research, 223, 114121.

Samuel, A. S. (1981) The role of bottom-up confirmation in phoneme restoration illusion. Journal of Experimental Psychology: Human Perception and Performance, 7, 11241131. 
Sheldon, S., Pichora-Fuller, M. K., \& Schneider, B. A. (2008) Effects of age, presentation method, and learning on identification of noise-vocoded words. Journal of the Acoustical Society of America, 123, 476-488.

Sommers, M. S., \& Danielson, S. M. (1999) Inhibitory processes and spoken word recognition in young and old adults: the interaction of lexical competition and semantic context. Psychology and Aging, 14, 458-472.

Van Petten, C., \& Kutas, M. (1990) Interactions between sentence context and word frequency in event-related brain potentials. Memory \& Cognition, 18, 380-393.

Wingfield, A., Tun, P. A., \& McCoy, S. L. (2005) Hearing loss in older adulthood: what it is and how it interacts with cognitive performance. Current Directions in Psychological Sciences, 14, 144-148.

Accepted October 13, 2010. 


\section{APPENDIX}

Lists of High-predictability Sentences With Their

Equivalent Lists of Low-Predictability Sentences

\begin{tabular}{|c|c|c|c|}
\hline High-predictability Sentences & Last Word & Low-predictability Sentences & Last Word \\
\hline List 1 & & List 1 & \\
\hline En el castillo se alza la & torre & Ha estado pronunciando & torre \\
\hline La explosión causó un & caos & Ellos escribieron & caos \\
\hline Iba vestida con falda y & blusa & Pronuncia la palabra & blusa \\
\hline Ata el regalo con una & cinta & Ahora voy a decir & cinta \\
\hline Guardo el dinero en el & bolso & Ella dijo la palabra & bolso \\
\hline Me tocó el primer & premio & Y a continuación dijo & premio \\
\hline Es un gran salón de & baile & No temas hablar del & baile \\
\hline Hay que limpiar, hay mucho & polvo & No discutieron sobre el & polvo \\
\hline El río sigue por su & cauce & Tu oíste que decía & cauce \\
\hline El ladrón pertenece a la & banda & Está interesado en decir & banda \\
\hline Amontónalo en una & pila & Juan no discute de la & pila \\
\hline Disparó con las flechas el & arco & Espero que hables de un & arco \\
\hline Cruzó el charco de un & salto & La niña sabía decir & salto \\
\hline Le gusta escurrir el & bulto & Laura no pudo hablar del & bulto \\
\hline Lleva la compra en la & bolsa & Les oí que hablaban de una & bolsa \\
\hline Me convenció con malas & artes & Carlos habló sobre las & artes \\
\hline Bebe la leche de la & taza & Deberías poder decir & taza \\
\hline No suelen comer carne de & cerdo & Estábamos pensando en un & cerdo \\
\hline Nos recibió en pijama y & bata & Ayer Luis soñó con una & bata \\
\hline De la cloaca salió una & rata & Ellos no consideraron la & rata \\
\hline Se revolcó en el sucio & barro & Laura estaba pronunciando & barro \\
\hline En el cielo hay bandadas de & aves & Es probable que hablen de unas & aves \\
\hline Son auténticos perros de & caza & No creas que voy a decir & caza \\
\hline Soplaba una suave & brisa & Lo que esta describiendo es la & brisa \\
\hline Todo se repite es un & ciclo & Adivina lo qué es un & ciclo \\
\hline List 2 & & ist 2 & \\
\hline Voy al museo de & cera & Ha estado pronunciando & cera \\
\hline Pronto alcanzarán la & cima & Ellos escribieron & cima \\
\hline Iba cargado como un & burro & Pronuncia la palabra & burro \\
\hline Llegó una hora tarde a su & cita & Ahora voy a decir & cita \\
\hline Dicen que habrá un cambio de & clima & Ella dijo la palabra & clima \\
\hline Yo estudio música y & danza & Y a continuación dijo & danza \\
\hline Voy al trabajo en & metro & No temas hablar del & metro \\
\hline Torció la boca en una & mueca & No discutieron sobre una & mueca \\
\hline Tómate caliente la & sopa & Tu oíste que decía & sopa \\
\hline Todos seguíamos al & guía & Está interesado en decir & guía \\
\hline Tiene una casa junto a un & lago & Juan no discute del & lago \\
\hline Tengo que podar esa & rama & Espero que hables de una & rama \\
\hline Te has pasado de la & raya & La niña sabía decir & raya \\
\hline Sírveme ginebra con & hielo & Laura no pudo hablar del & hielo \\
\hline Tengo el dinero en el & banco & Les oí que hablaban del & noble \\
\hline Se requiere vestido de & gala & Carlos habló sobre la & gala \\
\hline Dormimos hasta el & alba & Deberías poder decir & alba \\
\hline Se dejó la comida en el & plato & Estábamos pensando en un & plato \\
\hline Se bebió el vino de un & trago & Ayer Luis soñó con un & trago \\
\hline La carta lleva su & firma & Ellos no consideraron la & firma \\
\hline Refresca mucho chupar un & polo & Laura estaba pronunciando & polo \\
\hline Reduce la emisión de & gases & Es probable que hablen de unos & gases \\
\hline Por fin han derribado el & muro & No creas que voy a decir & muro \\
\hline Paramos para hacer una & pausa & Lo que esta describiendo es la & pausa \\
\hline Para leer necesita & gafas & Adivina lo qué son unas & gafas \\
\hline
\end{tabular}




\begin{tabular}{|c|c|c|c|}
\hline High-predictability Sentences & Last Word & Low-predictability Sentences & Last Word \\
\hline List 3 & & List 3 & \\
\hline Para entrar necesitas un & pase & Ha estado pronunciando & pase \\
\hline Colecciona objetos de & lujo & Ellos escribieron & lujo \\
\hline Nos guiamos siguiendo el & mapa & Pronuncia la palabra & mapa \\
\hline Nos despertó el canto del & gallo & Ahora voy a decir & gallo \\
\hline No quiero meter la & pata & Ella dijo la palabra & pata \\
\hline Sirve a una causa muy & noble & Y a continuación dijo & noble \\
\hline No lo acabes, guárdame un & trozo & No temas hablar del & trozo \\
\hline No cabía en sí de & gozo & No discutieron sobre el & gozo \\
\hline No arañes con esas & uñas & Tu oíste que decía & uñas \\
\hline Mete la guitarra en su & funda & Está interesado en decir & funda \\
\hline Me obligan a seguir esa & norma & Juan no discute de la & norma \\
\hline Me gusta cantar en la & ducha & Espero que hables de una & ducha \\
\hline Llevaba un pañuelo de & seda & La niña sabía decir & seda \\
\hline Llego tarde, cogeré un & taxi & Laura no pudo hablar del & taxi \\
\hline Los leones viven en la & selva & Les oí que hablaban de la & selva \\
\hline Los católicos van a & misa & Carlos habló sobre la & misa \\
\hline Lo mediré con una & regla & Deberías poder decir & regla \\
\hline Le regaló un ramo de & rosas & Estábamos pensando en unas & rosas \\
\hline Le gusta el fútbol y los & toros & Ayer Luis soñó con unos & toros \\
\hline Le golpeó con un & palo & Ellos no consideraron el & palo \\
\hline Las maletas las lleva el & mozo & Laura estaba pronunciando & mozo \\
\hline La sangre corre por sus & venas & Es probable que hablen de unas & venas \\
\hline La pluma mancha de & tinta & No creas que voy a decir & tinta \\
\hline La modista compra una & tela & Lo que esta describiendo es la & tela \\
\hline La lengua mas hablada es el & chino & Adivina lo qué es un & chino \\
\hline List 4 & & List 4 & \\
\hline La escayola inmoviliza el & hueso & Ha estado pronunciando & hueso \\
\hline La actriz no soportó la & fama & Ellos escribieron & fama \\
\hline Juega al ajedrez y las & damas & Pronuncia la palabra & damas \\
\hline Juan fue a un colegio de & curas & Ahora voy a decir & curas \\
\hline Haz un hoyo con pala y & pico & Ella dijo la palabra & pico \\
\hline Hay que resolver ciertas & dudas & Y a continuación dijo & dudas \\
\hline Guarda bien el dinero y las & joyas & No temas hablar de unas & joyas \\
\hline En el cielo no se ven & nubes & No discutieron sobre unas & nubes \\
\hline Fue escrito con su propia & letra & Tu oíste que decía & letra \\
\hline Este piso no está en & venta & Está interesado en decir & venta \\
\hline Estás rayado como un & disco & Juan no discute de un & disco \\
\hline Estaba encerrado en la & jaula & Espero que hables de una & jaula \\
\hline Es un sagrado lugar de & culto & La niña sabía decir & culto \\
\hline Es un consumidor de & droga & Laura no pudo hablar de la & droga \\
\hline Es un bolso negro de & cuero & Les oí que hablaban del & cuero \\
\hline Es letal a ciertas & dosis & Carlos habló sobre la & dosis \\
\hline Es el primero de la & fila & Deberías poder decir & fila \\
\hline Es el militar de más & rango & Estábamos pensando en el & rango \\
\hline Es el colmo de todos los & males & Ayer Luis soñó con los & males \\
\hline Firmó un cheque con muchas & cifras & Ellos no consideraron las & cifras \\
\hline Era tan fiero como un & lobo & Laura estaba pronunciando & lobo \\
\hline Enciende la mecha de esa & vela & Es probable que hablen de una & vela \\
\hline En matemáticas es un & genio & No creas que voy a decir & genio \\
\hline En la urna deposito el & voto & Lo que esta describiendo es el & voto \\
\hline En la tormenta cayó un & rayo & Adivina lo qué es un & rayo \\
\hline List 5 & & List 5 & \\
\hline En la cola espero mi & turno & Ha estado pronunciando & turno \\
\hline En Italia comí mucha & pasta & Ellos escribieron & pasta \\
\hline En el mar hay grandes & olas & Pronuncia la palabra & olas \\
\hline
\end{tabular}




\begin{tabular}{|c|c|c|c|}
\hline High-predictability Sentences & Last Word & Low-predictability Sentences & Last Word \\
\hline En el mapa sigue la & ruta & Ahora voy a decir & ruta \\
\hline En el informe nos falta un & dato & Ella dijo la palabra & dato \\
\hline Fue herido con una & lanza & Y a continuación dijo & lanza \\
\hline La nota mínima es un & cero & No temas hablar del & cero \\
\hline En el camino pinché una & rueda & No discutieron sobre la & rueda \\
\hline El viento levantó su & falda & Tu oíste que decía & falda \\
\hline Casi me muero del & susto & Está interesado en decir & susto \\
\hline El tren circula por las & vías & Juan no discute de las & vías \\
\hline El silencio fue en señal de & duelo & Espero que hables de un & duelo \\
\hline El seguro cubrirá los & daños & La niña sabía decir & daño \\
\hline Ella cargó con toda la & culpa & Laura no pudo hablar de la & culpa \\
\hline El rey se sienta en su & trono & Les oí que hablaban de un & trono \\
\hline El pescador recoge las & redes & Carlos habló sobre las & redes \\
\hline El palacio pertenece al & duque & Deberías poder decir & duque \\
\hline El detective sigue la & pista & Estábamos pensando en una & pista \\
\hline El barco encalló en las & rocas & Ayer Luis soñó con unas & rocas \\
\hline El anillo se lo puso el & novio & Ellos no consideraron al & novio \\
\hline El abuelo cuida de su & nieto & Laura estaba pronunciando & nieto \\
\hline El poeta le escribió un & verso & Es probable que hablen de un & verso \\
\hline Duermo con un cojín de & plumas & No creas que voy a decir & plumas \\
\hline Devuelve lo robado a su & dueña & Lo que esta describiendo es la & dueña \\
\hline Es austero como un & monje & Adivina lo qué es un & metal \\
\hline List 6 & & List 6 & \\
\hline Se despidió con un & beso & Ha estado pronunciando & beso \\
\hline La soprano da clases de & canto & Ellos escribieron & canto \\
\hline Corta el tallo y las & hojas & Pronuncia la palabra & hoja \\
\hline Para abrir la puerta tengo & llave & Ahora voy a decir & llave \\
\hline Cogió con sus garras la & presa & Ella dijo la palabra & presa \\
\hline El tren entró en el oscuro & túnel & Y a continuación dijo & túnel \\
\hline Canta de tenor en un & coro & No temas hablar del & coro \\
\hline El caballo tira del & carro & No discutieron sobre el & carro \\
\hline Al mar van a desembocar los & ríos & Tu oíste que decía & ríos \\
\hline $\mathrm{Al}$ correr se me acelera el & pulso & Está interesado en decir & pulso \\
\hline Al caer se dio en la & nuca & Juan no discute de la & nuca \\
\hline A la miel acuden las & moscas & Espero que hables de unas & moscas \\
\hline Deja el niño en la & cuna & La niña sabía decir & cuna \\
\hline Brindamos alzando la & copa & Laura no pudo hablar de la & copa \\
\hline El siempre gasta pesadas & bromas & Les oí que hablaban de unas & bromas \\
\hline La historia tiene una buena & trama & Carlos habló sobre la & trama \\
\hline Espere su turno en la & cola & Deberías poder decir & cola \\
\hline Tengo asiento en primera & fila & Estábamos pensando en una & fila \\
\hline El ratón cayo en la & trampa & Ayer Luis soñó con la & trampa \\
\hline Acampamos con nuestras & tiendas & Ellos no consideraron la & tienda \\
\hline El sabe como lanzar un & dardo & Laura estaba pronunciando & dardo \\
\hline De noche hay luz de & luna & Es probable que hablen de la & luna \\
\hline Corta la carne en pequeños & trozos & No creas que voy a decir & trozo \\
\hline No hubo heridos en el & choque & Lo que esta describiendo es el & choque \\
\hline El árbitro hizo sonar el & pito & Adivina lo qué es un & pito \\
\hline
\end{tabular}

